\title{
Interaction of Boron with Copper and Its Influence on Matrix of Spheroidal Graphite Cast Iron
}

\author{
Ying ZOU, ${ }^{1)}$ Motoharu OGAWA2) and Hideo NAKAE ${ }^{3)}$ \\ 1) Graduate student, Waseda Univ., 3-4-1, Okubo, Shinjuku-ku, Tokyo, 169-8555 Japan. E-mail: zouying@akane.waseda.jp \\ 2) Formerly Graduate student, Waseda University. Now at Sumitomo Metals, Ibaragi, 314-0014 Japan. E-mail: ogawa-mth \\ @simotomometals.co.jp $\quad 3)$ Lab. For Mater. Sci. \& Tech., Waseda Univ., 2-8-26, Nishi-waseda, Shinjuku-ku, Tokyo, 169- \\ 0051 Japan. E-mail: h.nakae@waseda.jp
}

(Received on August 19, 2011; accepted on November 8, 2011)

\begin{abstract}
High strength steel, which often contains a few tens of ppm B, has been used in the automobile industry due to weight reduction for energy savings. If this steel scrap is recycled for producing high strength spheroidal graphite iron castings, the alloying element, $B$, changes the matrix from pearlite to ferrite. In this research, the influence of $B$ on the matrix of the high strength spheroidal graphite iron castings and the means of counteracting its bad effects were investigated.

The result of the study on the ferritization effect of $B$ on the matrix showed that the ferrite volume fraction increased with the addition of B. Meanwhile, the smoothness of the spheroidal graphite surface was damaged.

In order to investigate the counteracting measures to the ferritization effect of $\mathrm{B}, \mathrm{N}$ or Ti was added to the parent alloy to form $\mathrm{BN}$ or $\mathrm{TiB}_{2}$. It was found that the addition of $\mathrm{N}$ or $\mathrm{Ti}$ reduced the ferrite volume fraction slightly, and the effect of Ti was more obvious.

Some tests were carried out to discuss the interaction of $\mathrm{Cu}$ with $\mathrm{B}$. The existence of a thin $\mathrm{Cu}$ film on the spheroidal graphite surface was observed in the B-free Cu-added sample; nevertheless, it could not be confirmed in the B-added sample. When $\mathrm{Cu}$ was replaced by $\mathrm{Mn}$, there was no difference in the ferrite fraction with the $B$ addition. Therefore, it could be confirmed that the ferritization effect of $B$ exists only in the presence of $\mathrm{Cu}$ in spheroidal graphite cast iron.
\end{abstract}

KEY WORDS: spheroidal graphite; high strength cast iron; high strength steel; boron; ferrite; copper.

\section{Introduction}

It is widely accepted that the matrix is critical to the comprehensive properties of spheroidal graphite cast iron. For high strength spheroidal graphite cast iron, pearlite is the ideal matrix, and then $\mathrm{Cu}$ is an element that facilitating cast iron with higher tensile strength without chill formation. In the past, much research work ${ }^{1-4)}$ has been done on the effect of $\mathrm{Cu}$ on the matrix structure and the graphite morphology, and researchers have come to realize that $\mathrm{Cu}$ has an appealing feature of pearlite stabilization in the spheroidal graphite cast iron. Nowadays, the high strength steel scrap, recycled from the automobile industry, which often contains a few tens of ppm of B, is usually used in the casting industry, and the existence of B induces the tensile strength reduction for the high strength spheroidal graphite iron castings. 5,6 )

According to the study done by Izui et al., ${ }^{5)}$ even a few tens of ppm B has an adverse impact on the matrix in the high-strength spheroidal graphite cast iron alloyed with $\mathrm{Cu}$, in that $\mathrm{B}$ could increase the ferrite fraction of the cast iron. If the $\mathrm{B}$ content is more than $50 \mathrm{ppm}$, carbide appears in the matrix. $^{5,6)}$ Izui $^{5)}$ reported that $\mathrm{B}$ segregates around the spheroidal graphite to form $\mathrm{Fe}_{23}(\mathrm{CB})_{6}$ in the samples alloyed with $\mathrm{Cu}$, which dramatically lowers the carbon content in the matrix near the spheroidal graphite and leads to the ferrite matrix. These phenomena indicated that there could be some interaction between $\mathrm{Cu}$ and $\mathrm{B}$, but there was no detailed study either on explaining the mechanism or whether it is a particular phenomenon. On the other hand, in order to increase the pearlite fraction in the matrix for higher tensile strength, one method was proposed in which a strong pearlite-forming element such as Sn was added to the melt.

Umehara et $a l .{ }^{7)}$ showed that the desulfurization treatment of cupola melt could lessen the $\mathrm{B}$ content by combining $\mathrm{B}$ with $\mathrm{O}$ to form $\mathrm{B}_{2} \mathrm{O}_{3}$; nevertheless, the result was not sufficient. Igarashi et al. ${ }^{8)}$ observed a secondary graphite precipitated on the spheroidal graphite surface by a SEM, using deep-etched samples alloyed with $\mathrm{Cu}$ and B; However, the existence of the $\mathrm{Cu}$ film was not clarified. Tsujikawa ${ }^{9}{ }^{9}$ also failed in finding the $\mathrm{Cu}$ film by a TEM observation. The existence of the thin $\mathrm{Cu}$ film around the spheroidal graphite was first confirmed by Ishiguro ${ }^{10)}$ using an in-lens type FESEM. However, the segregation mechanism of $\mathrm{Cu}$ has not been clarified.

In this research, a treatment to reduce the ferritization effect of $\mathrm{B}$ was examined by adding $\mathrm{N}$ or Ti to the cast iron melt. Then, in order to identify whether the interaction of $B$ with $\mathrm{Cu}$ is a particular phenomenon, the interaction of $\mathrm{B}$ with Mn was also studied. Finally, the distribution of B was 
investigated using a WDX, and the observation of the $\mathrm{Cu}$ film was also carried out to examine the interaction mechanism of $\mathrm{B}$ with $\mathrm{Cu}$.

\section{Experimental Procedure and the Alloy Compositions}

In an $\mathrm{Ar}$ atmosphere, carbon steel rods $(\mathrm{Fe}-0.25 \% \mathrm{C}-$ $0.14 \% \mathrm{Si}-0.18 \% \mathrm{Mn}-0.017 \% \mathrm{P}-0.021 \% \mathrm{~S})$, graphite electrode and ferro-manganese were melted in a high-frequency induction furnace. After that, metallic silicon and pure copper were added to the melt. High purity ferro-boron $(14.6 \% \mathrm{~B})$ was added to the melt to study the influence of $\mathrm{B}$ on the matrix. Ferro-manganese nitride $(4.66 \% \mathrm{~N})$ and sponge titanium $(98 \% \mathrm{Ti})$ were also added to the melt to study the effect of $\mathrm{N}$ and Ti, respectively. Thermal analysis was done during the melting using a CE-cup, and the carbon equivalent was adjusted to $4.4 \%$. An inoculant $(22 \% \mathrm{Fe}-$ $75 \% \mathrm{Si}-3 \% \mathrm{Ca})$ and a spheroidizer $(48 \% \mathrm{Fe}-45.4 \% \mathrm{Si}-1.54 \%$ $\mathrm{Ca}-3.67 \% \mathrm{Mg}-1.71 \% \mathrm{RE}$ ) were added in a ladle, and the melt was then cast into knock-off type keel blocks of $25 \mathrm{~mm}$ diameter. The chemical compositions of B-added, B-Nadded, and B-Ti-added alloys used in this study are shown in Tables 1, 2 and 3, respectively.

The samples were polished and then etched with 3\% nital for about ten seconds until the metallic luster was lost. The

Table 1. Chemical composition of B-added samples.

\begin{tabular}{cccccc}
\hline $\begin{array}{c}\text { Number of } \\
\text { sample }\end{array}$ & $\mathrm{C}$ & $\mathrm{Si}$ & $\mathrm{Cu}$ & $\mathrm{B}$ & $\mathrm{Mn}$ \\
\hline 1 & 3.62 & 2.52 & 1.09 & $<5 \mathrm{ppm} *$ & 0.44 \\
2 & 3.65 & 2.64 & 0.95 & $5 \mathrm{ppm}$ & 0.43 \\
3 & 3.61 & 2.53 & 1.08 & $10 \mathrm{ppm}$ & 0.41 \\
4 & 3.57 & 2.50 & 1.07 & $15 \mathrm{ppm}$ & 0.44 \\
5 & 3.66 & 2.56 & 1.14 & $31 \mathrm{ppm}$ & 0.44 \\
\hline
\end{tabular}

*: 5 ppm B is the lower limit of this chemical analysis.

Table 2. Chemical composition of $\mathrm{N}$-added samples.

\begin{tabular}{ccccccc}
\hline $\begin{array}{c}\text { Number of } \\
\text { sample }\end{array}$ & $\mathrm{C}$ & $\mathrm{Si}$ & $\mathrm{Cu}$ & $\mathrm{B}$ & $\mathrm{N}$ & $\mathrm{Mn}$ \\
\hline 6 & 3.62 & 2.52 & 1.09 & $<5 \mathrm{ppm} *$ & $84 \mathrm{ppm}$ & 0.62 \\
7 & 3.65 & 2.64 & 0.95 & $4 \mathrm{ppm}$ & $81 \mathrm{ppm}$ & 0.66 \\
8 & 3.61 & 2.53 & 1.08 & $10 \mathrm{ppm}$ & $95 \mathrm{ppm}$ & 0.66 \\
9 & 3.57 & 2.50 & 1.07 & $15 \mathrm{ppm}$ & $85 \mathrm{ppm}$ & 0.67 \\
10 & 3.66 & 2.56 & 1.14 & $38 \mathrm{ppm}$ & $89 \mathrm{ppm}$ & 0.61 \\
\hline
\end{tabular}

Table 3. Chemical composition of Ti-added samples.

\begin{tabular}{ccccccc}
\hline $\begin{array}{c}\text { Number of } \\
\text { sample }\end{array}$ & $\mathrm{C}$ & $\mathrm{Si}$ & $\mathrm{Cu}$ & $\mathrm{B}$ & $\mathrm{Ti}$ & $\mathrm{Mn}$ \\
\hline 11 & 3.62 & 2.52 & 1.09 & $<5 \mathrm{ppm} *$ & $588 \mathrm{ppm}$ & 0.63 \\
12 & 3.65 & 2.64 & 0.95 & $8 \mathrm{ppm}$ & $516 \mathrm{ppm}$ & 0.65 \\
13 & 3.61 & 2.53 & 1.08 & $11 \mathrm{ppm}$ & $613 \mathrm{ppm}$ & 0.67 \\
14 & 3.57 & 2.50 & 1.07 & $21 \mathrm{ppm}$ & $486 \mathrm{ppm}$ & 0.67 \\
15 & 3.66 & 2.56 & 1.14 & $37 \mathrm{ppm}$ & $601 \mathrm{ppm}$ & 0.61 \\
\hline
\end{tabular}

macro- and microstructures of the samples were then observed by an optical microscope and a SEM. In order to observe the graphite surface morphology with the SEM, the samples were deeply etched in $10 \%$ nital for about 25 minutes.

For the observation of the $\mathrm{Cu}$ film on the graphite surface, the $\mathrm{Fe}$ in the matrix should be etched without the dissolution of $\mathrm{Cu}$. Therefore, a special corrosion method was introduced into this research using a degassed $\mathrm{HCl}$ aqueous solution. Firstly, pure water was degassed for 1 hour by vacuum treatment. After that, $\mathrm{HCl}$ was added into the water at $7 \%$ and degassed for another 1 hour. Because of the difference in ionization tendency of $\mathrm{Fe}$ and $\mathrm{Cu}$ without oxygen in the solution, the $\mathrm{Fe}$ in the matrix was corroded, while the $\mathrm{Cu}$ film on the graphite surface remained with this etching method. ${ }^{11)}$ The ferrite volume fraction was measured using the $3 \%$ natal-etched samples with a microcomputer equipped with an optical microscope.

\section{Results and Discussion}

\subsection{Influence of $\mathrm{B}, \mathrm{N}$ and $\mathrm{Ti}$ on the Matrix}

\subsubsection{Influence of $\mathrm{B}$}

The microstructures of the matrix of the $1 \% \mathrm{Cu}$ spheroidal graphite cast iron at different B contents are shown in Fig. 1. The figure reveals that the pearlite volume fraction decreases with the increase in the B content. Where is the precipitated carbon with the ferrite formation? To study this problem, the three-dimensional shape of the spheroidal graphite surface was observed using the SEM, and the result was the same as that in Fig. 2. ${ }^{8}$ The spheroidal graphite surface was covered with a special kind of graphite, like the D-type graphite in flake graphite, because the precipitation of the carbon in austenite formed a secondary graphite. Since there was no $\mathrm{Cu}$ film, the precipitated secondary graphite formed a layer around the crystallized spheroidal graphite, as pointed out by the arrows in Fig. 3. We can eas-

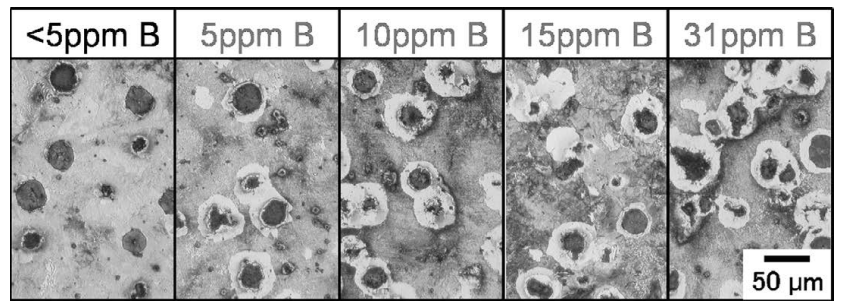

Fig. 1. Influence of $\mathrm{B}$ on the matrix structure of $1 \% \mathrm{Cu}$ spheroidal graphite cast iron.

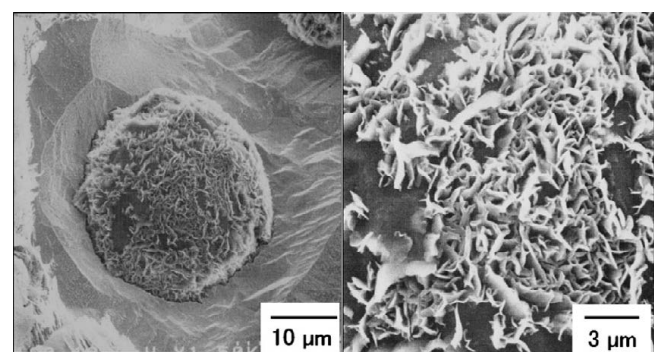

Fig. 2. ${ }^{8)}$ Spheroidal graphite surface of 31 ppm-B sample observed by SEM. 


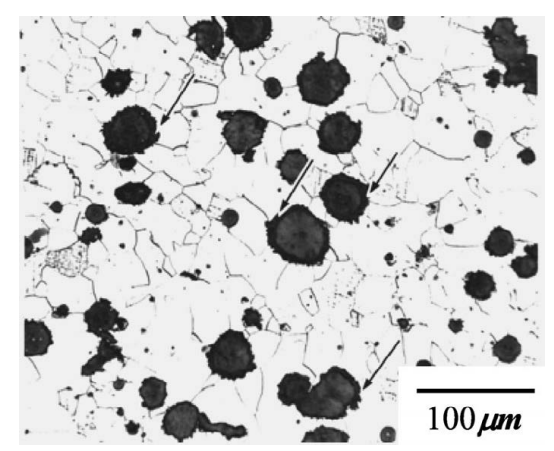

Fig. 3. All-ferrite matrix and secondary graphite precipitated spheroidal graphite iron.

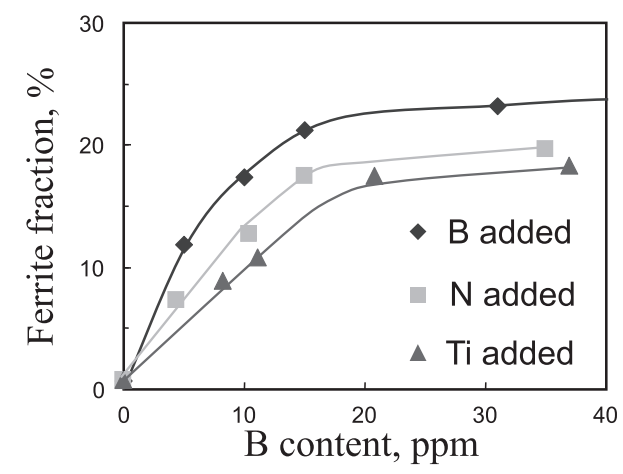

Fig. 4. Influence of added elements on ferrite fraction.

ily confirm the secondary graphite in all-ferrite-matrix spheroidal graphite iron due to its significant volume.

\subsubsection{Counteracting Effect of $\mathrm{N}$ and $\mathrm{Ti}$}

To investigate the counteraction to the damaging effect of $\mathrm{B}$ on the matrix, the addition of $\mathrm{N}$ or $\mathrm{Ti}$ was studied. Approximately $85 \mathrm{ppm} \mathrm{N}$ or $550 \mathrm{ppm}$ Ti was added to the alloys for controlling the ferrite volume fraction. The ferrite volume fraction decreased in the $\mathrm{N}$-treated and the Titreated samples as shown in Fig. 4. As for the effect of the pearlite formation, $\mathrm{Ti}$ is much more effective than $\mathrm{N}$ in restraining the ferrite formation and retaining the smoothness of the spheroidal graphite surface.

\subsubsection{Mechanism of Influence of $\mathrm{N}$ and $\mathrm{Ti}$}

As indicated above, the precipitated carbon from the austenite matrix during the cooling forms the D-type-like graphite at the spheroidal graphite surface of the B-added samples. If $\mathrm{N}$ or $\mathrm{Ti}$ is added to the samples, $\mathrm{B}$ reacts with $\mathrm{N}$ or Ti to form $\mathrm{BN}$ or $\mathrm{TiB}_{2}$, thus decreasing the dissolved $\mathrm{B}$ concentration in the austenite and weakening the ferrite formation tendency. The reason why $\mathrm{Ti}$ is much more effective than $\mathrm{N}$ could be explained by the chemical reaction and the free energy change shown in Eqs. (1) and (2). ${ }^{12)}$

$$
\begin{aligned}
& \mathrm{N}+\mathrm{B}=\mathrm{BN} \quad \Delta \mathrm{G}_{0}=-126840+94.5 \mathrm{~T}(\mathrm{~J} / \mathrm{mol} \text { of } \mathrm{B}) . . \\
& \mathrm{Ti}+2 \mathrm{~B}=\mathrm{TiB}_{2} \quad \Delta \mathrm{G}_{0}=-160230+2.94 \mathrm{~T}(\mathrm{~J} / \mathrm{mol} \text { of } \mathrm{B}) . .
\end{aligned}
$$

A thermodynamic calculation was done using these two equations; the results are shown in Fig. 5, via the influence of temperature on the boride formation energy $\Delta \mathrm{G}_{0}$. From Fig. 5, it is clear that at the eutectoid temperature, the formation energy of $\mathrm{TiB}_{2}$ is much lower than that of $\mathrm{BN}$.

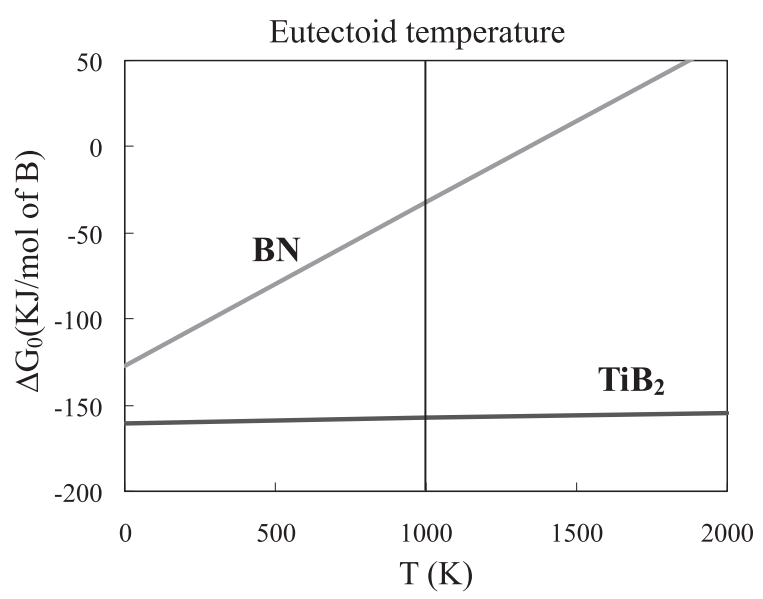

Fig. 5. Formation energy of $\mathrm{BN}$ and $\mathrm{TiB}_{2}$ at different temperatures.

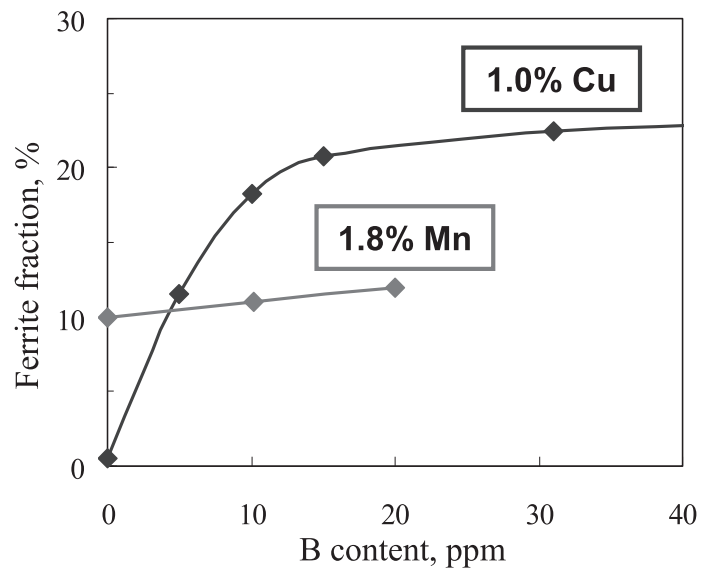

Fig. 6. Changes in ferrite fraction with B content in the samples alloyed with $\mathrm{Cu}$ or $\mathrm{Mn}$.

The difference in the formation energy of $\mathrm{BN}$ and $\mathrm{TiB}_{2}$ demonstrates that it is easier to form $\mathrm{TiB}_{2}$ than $\mathrm{BN}$ at the eutectoid temperature. Accordingly, $\mathrm{Ti}$ is much more effective than $\mathrm{N}$ in reducing the dissolved $\mathrm{B}$ concentration in the matrix and neutralizing the ferrite-forming effect of $\mathrm{B}$.

\subsection{The Interaction of $B$ with $\mathrm{Mn}$ and $\mathrm{Cu}$}

To investigate the interaction of $\mathrm{B}$ with $\mathrm{Mn}, 1.8 \% \mathrm{Mn}$ was added to the $\mathrm{Fe}-3.58 \% \mathrm{C}-2.54 \% \mathrm{Si}$ parent alloy at different contents of $\mathrm{B}$. The effects of $\mathrm{Mn}$ and $\mathrm{Cu}$ on the ferrite formation are compared in Fig. 6. It shows that there is little ferritization effect of B on the Mn-added samples, and the secondary graphite was not found on the spheroidal graphite surface, and Mn segregation at the grain boundary of the eutectic cell was confirmed with the Mn mapping in the matrix by the WDX, as shown in Fig. 7 .

When $1.0 \% \mathrm{Cu}$ was added to the same parent alloy, the ferrite fraction increased dramatically with the increase in B, as already shown in Fig. 1. Nevertheless, the ferrite fraction hardly changed in the Mn-added samples. Therefore, it could be concluded that the interaction between $\mathrm{B}$ and $\mathrm{Cu}$ is a peculiar phenomenon.

\subsection{Cu Film Observation}

It is estimated by many researchers that the pearlite-forming effect of $\mathrm{Cu}$ is due to the precipitation of a thin $\mathrm{Cu}$ film 


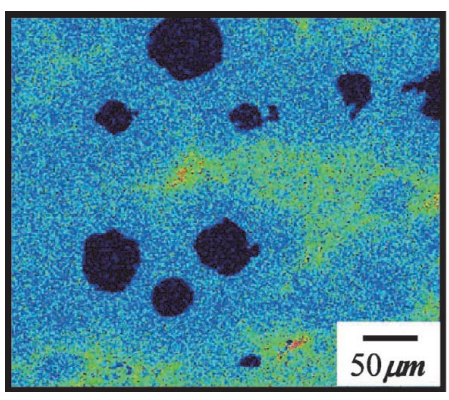

Mn concentration

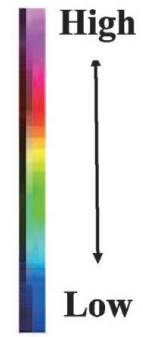

Fig. 7. Mn mapping in the matrix of the spheroidal graphite cast iron by the WDX.

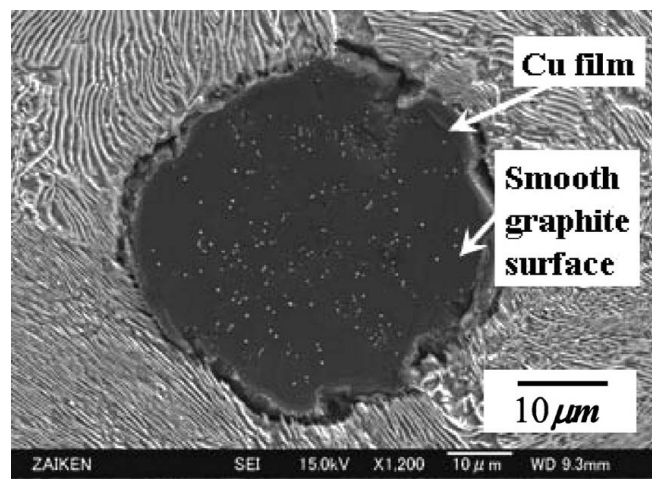

Fig. 8. Precipitation of thin $\mathrm{Cu}$ film around spheroidal graphite in the B-free sample.

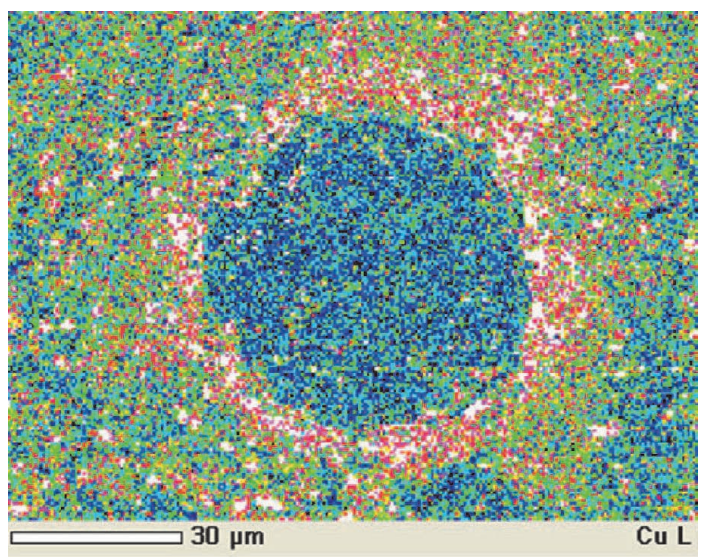

Fig. 9. Mapping of $\mathrm{Cu}$ film around spheroidal graphite in the Bfree sample by the EPMA analysis.

around the spheroidal graphite, which prevents the diffusion of carbon from the matrix to the spheroidal graphite. ${ }^{13)} \mathrm{Nev}-$ ertheless, nobody except Ishiguro $^{10)}$ could find the film. Therefore, we tried to find the film with the special etching technique, as already mentioned.

In the B-free sample, the existence of the $\mathrm{Cu}$ film was successfully detected as shown in the SEM image of Fig. 8. As can be seen clearly, the interface of the matrix/graphite was significantly etched, and the $\mathrm{Cu}$ film on the smooth spheroidal graphite surface was confirmed with the EPMA analysis, as in shown in Fig. 9. The matrix in Fig. 8 was fully pearlite and the spheroidal graphite surface was smooth. The reason why we could find the thin $\mathrm{Cu}$ film around the spheroidal graphite in the B-free sample is schematically demonstrated in Fig. 10. The $\mathrm{Cu}$ film acted as a barrier

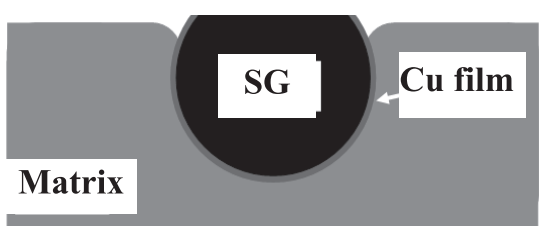

Fig. 10. Model of $\mathrm{Cu}$ film confirmed around spheroidal graphite in the B-free sample.

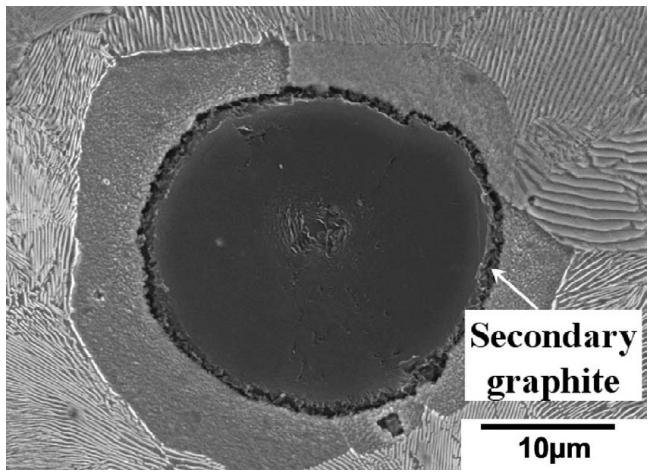

Fig. 11. Precipitation of secondary graphite on spheroidal graphite surface.

restraining the diffusion of carbon to the spheroidal graphite surface. ${ }^{13)}$ Hence, this maintained the high carbon concentration in the matrix and prevented the formation of the secondary graphite on the surface to form the all-pearlite matrix.

The observation of the $\mathrm{Cu}$ film in the sample with $\mathrm{B}$ was also done in the same way. However, we could not find any $\mathrm{Cu}$ film. The precipitated D-type-like graphite (secondary graphite) on the spheroidal graphite surface and the ferrite matrix around were confirmed, as shown in Fig. 11. Meanwhile, the graphite surface was quite coarse, which was of the identical phenomenon with that in Igarashi's report. ${ }^{8)}$

In order to investigate the distribution of $\mathrm{Cu}$ in the matrix, a mapping and point analysis with the WDX were done near the spheroidal graphite. In the sample with $\mathrm{B}$, very little $\mathrm{Cu}$ was detected on the spheroidal graphite surface, which indicated the absence of the $\mathrm{Cu}$ segregation. In this case, it was easier for the carbon to diffuse from the matrix to the spheroidal graphite surface to form the D-type-like graphite. Therefore, the matrix was ferrite and the precipitated secondary graphite was observed on the spheroidal graphite surface.

\subsection{Distribution of $B$}

If the idea that $\mathrm{B}$ reacts with $\mathrm{Cu}$ is correct, $\mathrm{B}$ should exist within the area of the $\mathrm{Cu}$ film. In order to confirm the distribution of $\mathrm{B}$, a mapping analysis was done using the WDX to detect $\mathrm{B}$ near the spheroidal graphite in the $31 \mathrm{ppm}-\mathrm{B}$ sample (polished, not etched). B was detected near the surface area of the spheroidal graphite, and there was no $\mathrm{Cu}$ film, as the interaction of $\mathrm{B}$ with $\mathrm{Cu}$ destroyed the continuity of the $\mathrm{Cu}$ film. Therefore, it is possible for the carbon to diffuse from the matrix to the spheroidal graphite. When the carbon concentration in the matrix near the spheroidal graphite becomes low enough, the matrix will change from pearlite to ferrite. 


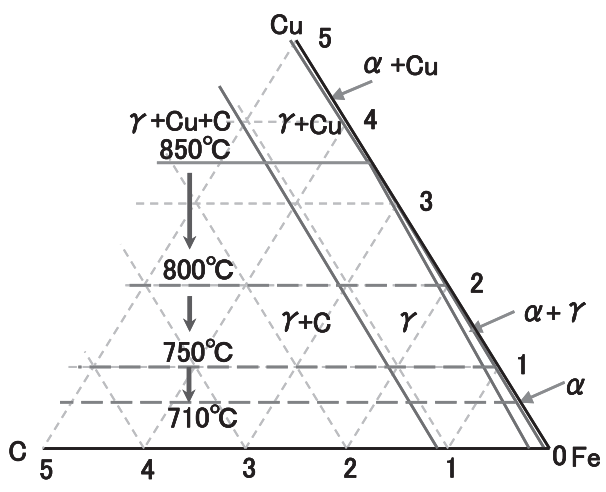

Fig. 12. Influence of temperature on solubility limit of $\mathrm{Cu}$ in $\mathrm{Fe}-$ $\mathrm{C}-\mathrm{Cu}$ ternary phase diagram.

\subsection{Precipitation of $\mathrm{Cu}$}

For the confirmation of the $\mathrm{Cu}$ film formation, a ternary phase diagram of $\mathrm{Fe}-\mathrm{C}-\mathrm{Cu}$ was calculated ${ }^{3,14)}$ and is shown in Fig. 12. The solubility limit of $\mathrm{Cu}$ decreases with the temperature and the dissolved $\mathrm{Cu}$ is precipitated at $750^{\circ} \mathrm{C}$ if the iron contains $1 \% \mathrm{Cu}$ and at $710^{\circ} \mathrm{C}$ for the $0.5 \% \mathrm{Cu}$ sample, as can be estimated in the figure. It is well known that the growth of the spheroidal graphite is controlled by the diffusion of carbon through the austenite shell. If the spheroidal graphite is covered with a $\mathrm{Cu}$ film, the diffusion rate is significantly low, and the carbon is enriched in the austenite to form the pearlite. This is believed to be the reason why $\mathrm{Cu}$ promotes the pearlite formation in the spheroidal graphite iron in the eutectoid transformation.

\section{Conclusions}

The influence of $\mathrm{B}$ on the matrix, the counteraction method using $\mathrm{N}$ and $\mathrm{Ti}$ to reduce the damaging effect of $\mathrm{B}$, the comparison of the interaction of $\mathrm{B}$ with $\mathrm{Cu}$ and $\mathrm{B}$ with $\mathrm{Mn}$, the distribution of $\mathrm{B}$ and the segregation mechanism of $\mathrm{Cu}$ were investigated in this research. The following points have been established in this study.
(1) B could increase the ferrite fraction in the matrix, coarsen the spheroidal graphite surface, and promote the formation of the secondary graphite on the spheroidal graphite iron alloyed with $\mathrm{Cu}$.

(2) The addition of $\mathrm{N}$ and $\mathrm{Ti}$ could neutralize the ferritization effect of $\mathrm{B}$, while Ti is much more effective.

(3) The ferrite-forming effect of B only exists in the spheroidal graphite iron alloyed with $\mathrm{Cu}$.

(4) The $\mathrm{Cu}$ film around the spheroidal graphite was successfully observed in this research using FE-SEM with a special etching method of degassed $\mathrm{HCl}$ aqueous solution, and is believed to act as a barrier to the carbon diffusion, maintaining the pearlite morphology in the matrix. The formation of it is the result of the solubility limit of $\mathrm{Cu}$ in the $\mathrm{Fe}-\mathrm{C}-\mathrm{Cu}$ ternary alloy.

(5) In the samples alloyed with $\mathrm{Cu}, \mathrm{B}$ is distributed on the spheroidal graphite surface.

\section{REFERENCES}

1) J. G. Pearce and K. Bromage: Copper in Cast Iron (translated version in Japanese), ed. by H. Tonami, Agne Co. Ltd., Tokyo, (1966), 56, 97.

2) M. Murakami, Y. Takanaga, N. Nakada, T. Tsuchiyama and S. Takaki: ISIJ Int., 48 (2008), 1467.

3) Lars-Erik Larsson: Z. Metallkd., 66 (1975), 220.

4) A. De Sy: Cu Technol., 6 (1967), 12

5) S. Izui, N. Furumiya, H. Horie, T. Kowata and T. Takahashi: IMONO, 66 (1994), 745.

6) Casting Defects and Countermeasures, JFS, Tokyo, (2007), 183.

7) H. Umehara, A. Yoshida, H. Tateno, Y. Arakaki and K. Okauti: Reports of the 146th JFS Meeting, J. JFS., Tokyo, (2006), 66.

8) Y. Igarashi, S. Akiyama, T. Kanno, I. Kang, H. Nakae, H. Horie, S. Hiratsuka and T. Fujikawa: J. JFS., 82 (2010), 16.

9) M. Tsujikawa, N. Matsumoto, K. Nakamoto and Y. Michiura: Key Eng. Mater., 457 (2011), 151.

10) Y. Ishiguro, K. Ichino and E. Takasugi: Materia Jpn., 48 (2009), 624.

11) T. Watanabe and S. Nakabayashi: Introduction of ChemistryElectrochemistry of Electron Migration, Asakura Publishing, Tokyo, (1996), 46.

12) O. Kubaschewski and C. B. Alcok: Metallurgical Thermochemistry, Pergamon Press, Oxford, (1979), 296.

13) Heat Treatment of Steel, ed. by ISIJ, Maruzen Co. Ltd., Tokyo, (1957), 366.

14) P. Villars, A. Prince and H. Okamoto: Handbook of Ternary Alloy Phase Diagrams, ASM Int., Ohio, (1995), CD-ROM. 